\title{
FUNGSI BANK INDONESIA \\ SEBAGAI PENGAWAS PERBANKAN DI INDONESIA
}

\author{
Mutiara Hikmah*)
}

\begin{abstract}
Abstrak
This article giving elaboration regarding Bank Indonesia role as central bank that hold significant's role and position in Indonesian economic progress, so Bank Indonesia ought to take position in the change of economic system from command economy to market economy. Considering that circumstance the role of Bank Indonesia under Article 23D of Constitution of Republic Indonesia has been endorsed to promulgating Peraturan Bank Indonesia (Bank Indonesia Regulation) which is has same level with Presidential regulation. That regulation considers to the Bank Indonesia roles to accomplishing through implementation of Law Number 23 year 1999 regarding Bank Indonesia. Under the Law central bank have responsibility to assure and conserve toward rupiah stability, monetary policy, continuity of payment system and banking supervision
\end{abstract}

Kata kunci: fungsi pengawasan, perbankan, peraturan perundang-undangan

\section{Pendahuluan}

Bangsa Indonesia telah mengenal lembaga perbankan sejak dahulu dengan segala perkembangannya baik bentuk, macam atau jumlah maupun produk yang ditawarkannya. Pertumbuhan dunia perbankan saat ini sedemikian pesatnya. Bank tumbuh dan berkembang dalam masyarakat yang penuh dengan dinamika sehingga dalam usahanya tidak lepas dari keharusan memperhatikan faktor-faktor keadaan usaha sekelilingnya yang dapat disebut dengan business environment. Lingkungan usaha perbankan dijalankan oleh dua unsur pokok yaitu unsur perusahaan dan unsur keadaan persaingan dunia perbankan yang dipengaruhi oleh keadaan sosial, budaya politik, ekonomi, tehnologi dan hukum.'

-) Staf Pengajar Kelompok Mata Kuliah Hukum Perdata Internasional dan Hukum dan HAM FHUl, anggota tim peneliti pada Sentra HAM FHUI dan peserta Program Doktor Program Pasca Sarjana FHUJ tahun akademik 2003.

I Ahlan Irsjan Sjarif, "COORPORATE FINANCE Perkembangan, Prospek dan Kendalanya Ditinjau dari Hukum Indonesia", makalah yang disampaikan dalam seminar 
Perbankan di Indonesia mempunyai asas, fungsi dan tujuan yaitu asas demokrasi ekonomi dengan menggunakan prinsip prudential banking (menerapkan prinsip kehati-hatian) dan fungsi utamanya sebagai financial intermediary $^{2}$ yang bertujuan meningkatkan pemerataan, pertumbuhan ekonomi dan stabilitas nasional kearah peningkatan kesejahteraan rakyat. ${ }^{3}$

Salah satu fungsi perbankan adalah menyalurkan dana kepada masyarakat dalam bentuk kredit. Kredit merupakan penyediaan uang berdasarkan kesepakatan antara bank dan nasabah debitur dengan kewajiban debitur melunasi hutangnya setelah jangka waktu tertentu berikut bunganya. ${ }^{4}$

Bank adalah bagian dari sistem keuangan dan sistem pembayaran suatu negara dan mempunyai peranan yang sangat penting dalam kedua sistem tersebut. Dalam rangka pembangunan Negara Indonesia, perbankan Indonesia diberi peranan yang strategis oleh Undang-Undang Perbankan sebagai salah satu sarana dalam menyerasikan dan menyeimbangkan masingmasing unsur dari Trilogi Pembangunan, yaitu pemerataan pembangunan, pertumbuhan ekonomi dan stabilitas nasional.

Karena sektor perbankan merupakan instrumen yang sangat penting bagi pertumbuhan perekonomian, serta berkaitan langsung dengan kepentingan masyarakat luas, maka sektor ini mendapat pengaturan yang intens dari segi yuridis. Dapat dikatakan bahwa sektor perbankan merupakan salah satu sektor bisnis yang sarat dengan aturan. ${ }^{5}$ Sehingga dapat diperhatikan bahwa cukup banyak aturan mulai dari tingkat undang-undang, keputusan presiden, peraturan pemerintah sampai dengan aturan yang lebih rendah seperti keputusan menteri keuangan, dan Keputusan Direksi Bank Indonesia yang merupakan dasar hukum dari perbankan di Indonesia.

sehari perbankan: Aspek Hukum Dalam Coorporate Finance Oleh Perbankan Di Indonesia, yang diselenggarakan di Fakultas Hukum UI (Depok, 17 Juli 2006), hal. 2.

2 Financial intermediary diartikan sebagai perantara pembiayaan, pialang pembiayaan, yaitu lembaga atau organisasi yang beroperasi pada pasar uang yang memungkinkan para pembeli, penjual, penghutang dan pemberi pinjaman bertemu dengan mudah. (Lihat Kamus Hukum Ekonomi ELIPS, hal. 64).

\footnotetext{
${ }^{3}$ Ahlan Sjarif, Loc. Cit., hal. 4.

${ }^{4}$ Ibid., hal. 3 .
}

5 Pradjoto, "Aspek Hukum Jaminan Dalam Coorporate Financing oleh Perbankan di Indonesia: Aturan Penegakan dan Penyelesaian Sengketa hukum Dalam Hubungan Kreditur dan Debitur". makalah yang disampaikan dalam seminar sehari perbankan: Aspek Hukum Dalam Coorporate Finance Oleh Perbankan Di Indonesia, yang diselenggarakan oleh Jurnal Hukum dan Pembangunan di Fakultas Hukum UI (Depok, 17 Juli 2006), hal. 2. 
Ada dua undang-undang utama yang berlaku bagi perbankan Indonesia. Yang pertama adalah undang-undang yang mengatur mengenai Bank Sentral, Yang kedua adalah Undang-Undang Perbankan. UndangUndang Bank Sentral mula-mula diatur dengan Undang-Undang No. 13 Tahun 1968 tentang Bank Sentral yang diundangkan pada tanggal 7 Desember 1968. Undang-Undang ini kemudian telah diganti dengan UndangUndang No. 23 Tahun 1999 tentang Bank Indonesia. Sedangkan UndangUndang Perbankan mula-mula diatur dalam Undang-Undang No. 7 Tahun 1992 tentang Perbankan yang diundangkan pada tanggal 25 Maret 1992. Undang-Undang ini kemudian telah diganti dengan Undang-Undang No. 10 tahun 1998 tentang Perubahan Atas Undang-Undang No. 7 Tahun 1992 tentang Perbankan.

"Pembinaan dan pengawasan bank dilakukan oleh Bank Indonesia" demikian amanat yang diberikan di dalam Pasal 29 ayat (1) Undang-Undang No. 10 Tahun 1998 tentang Perbankan dan juga diatur di dalam Pasal 24 Undang-Undang No. 23 Tahun 1999 tentang Bank Indonesia. Dari amanat tersebut, dapatlah dikatakan bahwa peran serta fungsi Bank Indonesia sebagai pengawas perbankan di Indonesia menjadi begitu penting untuk dikaji dan dipahami dengan lebih mendalam lagi.

\section{Bank Indonesia Sebagai Pengawas Perbankan}

Sebagai pembina dan pengawas perbankan di Indonesia, Bank Indonesia dalam menjalankan peran dan fungsinya tidak terlepas dari tujuannya yang diatur secara eksplisit di dalam undang-undang. Tujuan Bank Indonesia adalah mencapai dan memelihara kestabilan nilai rupiah. ${ }^{6}$ Dalam peraturan yang lama (yaitu UU No.13 Tahun 1968 tentang Bank Sentral, Pasal 7) tugas pokok Bank Indonesia diatur secara rinci yaitu membantu Pemerintah dalam hal:

- Mengatur, menjaga dan memelihara stabilitas nilai tukar;

- Mendorong kelancaran produksi dan pembangunan; serta

- Memperluas kesempatan kerja; guna meningkatkan taraf hidup rakyat.

Dalam menjalankan tugas sebagai pembinaan terhadap bank, Bank Indonesia mempunyai kewenangan-kewenangan sebagai berikut?

${ }^{6}$ Indonesia (A). Undang-Undang No. 23 Tahun 1999 tentang Bank Indonesia. Pasal 
- Memberikan dan mencabut izin usaha bank

- Memberikan izin pembukaan, penutupan dan pemindahan kantor bank.

- Memberikan persetujuan atas kepemilikan dan kepengurusan bank

- Memberikan izin kepada bank untuk menjalankan kegiatankegiatan usaha tertentu.

Dalam menjalankan tugas sebagai pengawasan terhadap bank, Bank Indonesia melakukan pengawasan secara langsung dan tidak langsung, ${ }^{8}$ serta dilakukan baik secara berkala maupun setiap waktu apabila diperlukan. ${ }^{9}$ Tugas pembinaan dan pengawasan perbankan yang dijalankan oleh Bank Indonesia, sangat berhubungan dengan fungsi Bank Indonesia sebagai Bank Sentral.

\section{A. Bank Indonesia sebagai Bank Sentral}

Bank adalah badan usaha yang menghimpun dana bagi masyarakat dalam bentuk simpanan, dan menyalurkannya kepada masyarakat dalam bentuk kredit dan atau bentuk-bentuk lainnya dalam rangka meningkatkan hidup rakyat banyak. ${ }^{10}$ Bank merupakan bagian dari sistem keuangan dan sistem pembayaran suatu negara dan mempunyai peran yang sangat penting dalam kedua sistem tersebut.

Bank Indonesia merupakan satu-satunya bank di Indonesia yang mengemban fungsi sebagai bank sentral. Pelaksanaan fungsi dari suatu bank sentral memegang peranan yang sangat penting dan sangat menentukan dalam kehidupan perekonomian suatu negara. Demikian berpengaruhnya bagi kehidupan perekonomian negara, sehingga Bank Indonesia sebagai bank sentral harus berkiprah sejalan dengan perubahan tatanan perekonomian yang sedang berlangsung, yaitu dari command economy ${ }^{11}$ kepada market economy. ${ }^{12}$

${ }^{7}$ Ibid., Pasal 26.

${ }^{8}$ Ibid., Pasal 27.

${ }^{9}$ Indonesia (B), Undang-Undang No. 10 Tahun 1998 tentang Perbankan. Pasal 31.

${ }^{10} \mathrm{Ibid}$., Pasal 1 ayat (2).

"Dalam command economy, pada umumnya aktivitas sehari-hari dari setiap orang ditentukan oleh para birokrat. 
Dalam market economy yang terbuka, tugas bank sentral menyangkut dua bidang, yaitu bidang moneter dan bidang perbankan. Dalam hubungan dengan kebijaksanaan bidang moneter, Bank Indonesia melakukan pengaturan mengenai jumlah uang beredar. Selain itu Bank Indonesia juga bertugas menjaga dan memelihara nilai tukar mata uang. Sedangkan di bidang perbankan, Bank Indonesia sebagai bank sentral bertugas untuk melakukan pembinaan dan pengawasan bank dalam rangka pengerahan dana masyarakat melalui perbankan, yang untuk tujuan itu harus dicapai melalui pemeliharaan tingkat kepercayaan masyarakat terhadap perbankan. ${ }^{13}$ Kepercayaan masyarakat terhadap perbankan juga akan tumbuh bila Bank Indonesia sebagai bank sentral memiliki kemandirian. Independensi Bank Indonesia merupakan faktor yang penting dan sangat menentukan di dalam bidang moneter dan perbankan di Indonesia.

\section{B. Independensi Bank Indonesia}

Penerapan konsep bank sentral yang bersifat mandiri (independen) merupakan konsep yang diterapkan di banyak negara, demikian pula di Indonesia. Tujuan penerapan konsep bank sentral yang independen adalah untuk meningkatkan kinerja ekonomi, terutama menjaga stabilitas harga barang-barang dan jasa-jasa. Dengan kata lain, tujuannya adalah menjaga agar tingkat inflasi serendah mungkin. ${ }^{i 4}$

Para ahli ekonomi yang mendukung konsep kemandirian, berpendapat bahwa hal ini sejalan dengan teori ekonomi yang mengemukakan bahwa yang dapat menggerakkan dan mendaya gunakan ekonomi secara maksimal adalah kemandirian. Konsep kemandirian mengenai bank sentral berpendirian bahwa untuk melaksanakan kemandirian itu diperlukan keahlian teknis, keadaan perekonomian yang baik negara yang bersangkutan, adanya kesabaran maupun pandangan yang jauh ke depan dari para penyelenggara negara.

Agar teori ekonomi yang berpendirian bahwa keberhasilannya tergantung kepada kemandirian itu akan dapat berjalan, maka

12 Dalam market economy, aktivitas seseorang terkoordinasi melalui sistem pasar. Sistem pasar memberikan kepada orang tanggung jawab yang lebih besar untuk menentukan bagi kepentingannya sendiri hal apa yang terbaik untuknya.

${ }^{13}$ Sutan Remy Sjahdeini, "Kapita Selekta Hukum Perbankan", Himpunan Tullisan Bahan Perkuliahan Hukum Perbankan Program Magister Hukum FHUl tahun 2000, hal. 73.

${ }^{14}$ Ibid., hal. 87. 
diperlukan adanya kebijaksanaan inflasi jangka menengah yang dapat dipercaya. Caranya ialah agar Pemerintah dalam rangka mencapai kestabilan harga menyerahkan kebijaksanaan moneter itu kepada suatu lembaga yang terpisah, yaitu bank sentral, dari yang memiliki otonomi dan memiliki keahlian teknis untuk dapat mencapai sasaran kebijaksanaan tersebut. Bukti keberhasilan teori ini didukung oleh kenyataan bahwa negara-negara yang mempunyai bank sentral yang independen pada umumnya memiliki tingkat inflasi yang lebih rendah.

Kemandirian bank sentral juga untuk menghindarkan penyalahgunaan penetapan tingkat bunga oleh Pemerintah. Hal ini sering terjadi di banyak negara. Contohnya di Indonesia adalah penetapan suku bunga untuk Kredit Investasi Kecil (KIK) dan Kredit Modal Kerja Permanen (KMKP) serta kredit-kredit khusus untuk petani, yang dananya untuk keperluan kredit-kredit itu tidak mungkin dapat diperoleh oleh bank dengan tingkat bunga rendah. Karena bankbank tidak mungkin memperoleh dana dari masyarakat dengan tingkat bunga pasar yang rendah, maka Bank Indonesia harus menyediakan Kredit Likuiditas Bank Indonesia (KLBI) untuk mendanainya, yang selanjutnya mengakibatkan tingkat inflasi yang tinggi.

Kemandirian Bank Indonesia telah dimantapkan dan ditegaskan di dalam Pasal 9 Undang-Undang BI. Pasal 9 ayat (1) menentukan bahwa "Pihak lain dilarang melakukan segala bentuk campur tangan terhadap pelaksanaan tugas Bank Indonesia...". Terhadap terjadinya campur tangan oleh pihak lain, antara lain yang datangnya dari Pemerintah, Pasal 9 ayat (2) memberikan kewenangan kepada Bank Indonesia untuk menolak dan atau mengabaikan segala bentuk campur tangan dari pihak manapun dalam rangka pelaksanaan tugasnya.

Bentuk formal yang biasanya dilakukan oleh Pemerintah dalam melakukan campur tangan terhadap pelaksanaan tugas Bank Indonesia adalah berupa kebijakan Pemerintah yang dituangkan di dalam Peraturan Pemerintah, Keputusan Presiden, Surat Keputusan Menteri dan beberapa bentuk peraturan perundang-undangan yang lain.

Dengan berlakunya ketentuan Pasal 9 ayat (2) Undang-Undang BI yang mewajibkan Bank Indonesia untuk menolak atau mengabaikan campur tangan pihak manapun, maka peraturan perundang-undangan yang dikeluarkan oleh Pemerintah yang dinilai oleh Bank Indonesia sebagai mencampuri tugas Bank Indonesia itu tidak akan mengikat Bank Indonesia. Dengan demikian, sekalipun peraturan perundangundangan itu eksis secara yuridis, tetapi tidak mempunyai efektivitas. Pilar kemandirian Bank Indonesia yang diatur di dalam Pasal 9 ayat (2) tersebut memberikan kekuatan bagi Bank Indonesia untuk mandiri. 
Bank Indonesia sebagai bank sentral selain harus memiliki sifat mandiri juga perlu menjunjung nilai-nilai akuntabilitas dan transparansi.

\section{Akuntabilitas dan Transparansi Bank Indonesia}

Akuntabilitas dan Transparansi Bank Indonesia perlu diperhatikan dan dikedepankan sejalan dengan status Bank Indonesia sebagai lembaga negara yang mandiri. Sebagai lembaga yang mandiri, Bank Indonesia independen dari pihak manapun juga, maka di dalam Undang-Undang tentang Bank Indonesia tidak mengatur pertanggungjawaban Bank Indonesia/Dewan Gubernur Bank Indonesia kepada lembaga negara tertentu. ${ }^{15}$

Bank Indonesia/Dewan Gubernur tidak bertanggungjawab kepada Presiden yang mengangkatnya dan tidak pula harus bertanggung jawab kepada Dewan Perwakilan Rakyat yang memberikan persetujuan atas usul pengangkatannya oleh Presiden. Bank Indonesia/Dewan Gubernur juga tidak harus bertanggung jawab kepada Majelis Permusyawaratan Rakyat. Di dalam Pasal 45 Undang-Undang Bank Indonesia, manantukan bahwa anggota Dewan Gubernur tidak dapat dihukum karena telah mengambil keputusan atau kebijakan yang sejalan dengan tugas dan wewenangnya yang ditentukan dalam Undang-Undang BI, sepanjang dilakukan dengan itikad baik.

Sekalipun Dewan Gubernur tidak harus bertanggung jawab kepada DPR, namun DPR dapat melakukan pengawasan dan melakukan audit terhadap kegiatan Bank Indonesia. Selain itu, Badan Pemeriksa Keuangan dapat melakukan pemeriksaan khusus terhadap Bank Indonesia atas permintaan DPR bila diperlukan.

Dewan Gubernur tidak dapat diberhentikan sewaktu-waktu sebelum masa jabatannya habis baik oleh Presiden yang mengangkatnya maupun oleh DPR yang memberikan persetujuan atas pengangkatan itu, tetapti Dewan Gubernur diwajibkan menyampaikan laporan perkembangan tugas dan wewenangnya kepada DPR setiap tiga bulan.

Undang-Undang Bank Indonesia mengatur mengenai kewajiban Bank Indonesia untuk melakukan transparansi kepada masyarakat. Di dalam Pasal 58 ayat (1), Bank Indonesia wajib menyampaikan informasi kepada masyarakat secara terbuka melalui media massa pada setiap awal tahun anggaran yang memuat:

${ }^{15}$ Ibid., hal. 96. 
a. evaluasi terhadap pelaksanaan kebijakan moneter pada tahun sebelumnya

b. rencana kebijakan moneter dan penetapan sasaran-sasaran moneter untuk tahun yang akan datang dengan mempertimbangkan sasaran laju inflasi serta perkembangan kondisi ekonomi dan keuangan.

Dalam ayat (2) pasal tersebut, mewajibkan Bank Indonesia menyampaikan informasi tersebut kepada Presiden dan DPR.

Apabila ternyata menurut penilaian masyarakat, evaluasi terhadap pelaksanaan kebijakan moneter pada tahun sebelumnya dinilai buruk atau informasi itu dinilai direkayasa untuk menyembunyikan keadaan yang sebenarnya, maka sekalipun sanksi hukum tidak ditentukan secara eksplisit oleh Undang-Undang BI, namun besar kemungkinannya sanksi politik dan sanksi moral akan dapat dialami oleh anggota Dewan Gubernur yang bersangkutan.

\section{Pembentukan Peraturan Perundang-Undangan}

Pembentukan sistem perundang-undangan suatu negara tidak akan terlepas dari sistem hukum suatu negara, karena peraturan perundangundangan sebagai hukum tertulis merupakan esensi atau bagian yang penting dari sistem hukum negara hukum modern yang demokratis. ${ }^{16}$

Peraturan perundang-undangan merupakan keseluruhan aturan tertulis yang dibuat oleh pejabat/lembaga negara pusat dan daerah yang berwenang untuk itu yang isinya mengikat secara umum. ${ }^{17}$ Peraturan perundangundangan sebagai bagian dari hukum tertulis dan merupakan bagian dari sistem hukum maka pengertian sistem peraturan perundang-undangan Indonesia adalah suatu rangkaian unsur-unsur hukum tertulis yang saling terkait, pengaruh-mempengaruhi, dan terpadu yang tidak dapat dipisahkan satu sama lainnya yang terdiri atas asas-asas, pembentuk dan pembentukannya, jenis, hierarkhi, fungsi, materi muatan, pengundangan, penyebarluasan, penegakan dan pengujian, yang semuanya dilandasi oleh falsafah Pancasila dan UUD Negara Republik Indonesia Tahun $1945 .^{18}$

16 H.A.S. Natabaya, "Sistem Peraturan Perundang-undangan Indonesia", cetakan pertama, (Jakarta: Sekretariat Jendral dan Kepaniteraan Mahkamah Konstitusi RI, 2006), hal. 7.

\footnotetext{
${ }^{17} \mathrm{Ibid}$., hal 17.

${ }^{18}$ Ibid.. hal. 18
} 
Sebagai suatu kesatuan yang integral, maka unsur-unsur dari sistem hukum dan sistem peraturan perundangan-undangan tersebut tidak dapat dipisahkan. Antara satu unsur dengan unsur yang lainnya saling pengaruh mempengaruhi.

Pada tanggal 22 Juni 2004 Presiden telah mengesahkan UndangUndang No. 10 Tahun 2004 tentang Pembentukan Peraturan Perundangundangan. ${ }^{19}$ Undang-undang ini merupakan hukum positif bagi Pembentukan Peraturan Perundang-undangan di Indonesia, yang salah satu isinya mengatur tentang asas-asas peraturan perundang-undangan.

\section{A. Asas-asas Peraturan Perundang-undangan}

Asas-asas yang berlaku dalam peraturan perundang-undangan dibagi menjadi tiga bagian yaitu: ${ }^{20}$

1. Asas-asas yang berkaitan dengan pembentukan peraturan perundang-undangan;

2. Asas-asas yang dikandung dalam materi muatan perundangundangan; dan

3. Asas lain sesuai dengan bidang hukum peraturan perundangundangan yang bersangkutan.

Asas-asas yang berkaitan dengan pembentukan peraturan perundang-undangan yang baik meliputi: ${ }^{21}$

1. Asas kejelasan tujuan;

2. Asas kelembagaan atau organ pembentuk yang tepat:

3. Asas kesesuaian antara jenis dan materi muatan:

4. Asas dapat dilaksanakan;

5. Asas kedayagunaan dan kehasilgunaan:

6. Asas kejelasan rumusan;

7. Asas keterbukaan.

Asas-asas yang dikandung dalam materi muatan peraturan perundang-undangan adalah: $:^{22}$ No. 4389.

${ }^{19}$ Diundangkan dalam Lembaran Negara RI No. 53. Tambahan Berita Negara RI

${ }^{20}$ H.A.S. Natabaya. Op. Cit.. hal. 33.

${ }^{21}$ Ibid., hal. 34.

22 Ibid., hal. 35. 
1. Asas pengayoman;

2. Asas kemanusiaan;

3. Asas kebangsaan;

4. Asas kekeluargaan

5. Asas kenusantaraan

6. Asas bhinneka tunggal ika

7. Asas keadilan

8. Asas kesamaan kedudukan dalam hukum dan pemerintahan

9. Asas ketertiban dan kepastian hukum

10. Asas keseimbangan, keserasian dan keselarasan

Asas lain sesuai dengan bidang hukum peraturan perundangundangan yang bersangkutan antara lain:

1. Dalam hukum pidana, misalnya asas legalitas, asas tiada hukuman tanpa kesalahan, asas pembinaan narapidana dan asas praduga tak bersalah;

2. Dalam hukum perdata, misalnya dalam hukum perjanjian berlaku asas-asas antara lain: asas kesepakatan para pihak, kebebasan berkontrak dan itikad baik.

Selain asas-asas pembentukan peraturan perundang-undangan yang baik, berlaku pula asas-asas antara lain: asas tata urutan/susunan (hirarki) peraturan perundang-undangan. Asas ini diadopsi dari teorinya Hans Kelsen tentang jenjang norma hukum (Stufenbau Theory) yang kemudian dikembangkan oleh muridnya yaitu Hans Nawiasky. Asas ini yang dipergunakan sebagai pisau analisis oleh lembaga peradilan baik Mahkamah Agung maupun Mahkamah Konstitusi untuk menguji suatu Peraturan Perundang-undangan. Disamping itu asas inipun dipergunakan oleh pemerintah pusat dan pemerintah prsi untuk menilai apakah suatu peraturan perundangundangan tingkat daerah bertentangan dengan peraturan perundangundangan yang lebih tinggi. ${ }^{23}$

Selain itu, asas-asas hukum umum yang secara khusus dapat diterapkan juga pada pembentukan peraturan perundang-undangan antara lain asas-asas: ${ }^{24}$

1. Lex specialis derogat lex generali (peraturan yang bersifat khhusus mengenyampingkan peraturan yang bersifat umum);

${ }^{23}$ Ibid.. hal. 38.

${ }^{24}$ Ibid. 
2. Lex posteriori derogate lex priori (peraturan yang dikeluarkan sesudahnya, mengenyampingkan peraturan yang dikeluarkan sebelumnya);

3. Lex superior derogate lex inferiori (peraturan yang lebih tinggi mengenyampingkan peraturan yang lebih rendah).

Selain mengenai asas-asas peraturan perundang-undangan, hal penting yang juga diatur di dalam Undang-Undang No. 10 Tahun 2004 adalah tentang jenis dan tata urutan peraturan perundang-undangan.

\section{B. Jenis dan Tata Urutan Peraturan Perundang-undangan}

Dalam perjalanan sejarah peraturan perundang-undangan Indonesia, jenis dan tata urutan/susunan (hirarki) peraturan perundangundangan mengalami perubahan sesuai dengan perubahan dan perkembangan kostitusi dan peraturan perundang-undangan yang berlaku di Indonesia.

Pada masa Orde Lama, Presiden Soekarno melalui Surat Presiden No. 3639/HK/ 59 tanggal 26 November 1959 menyebutkan bentukbentuk peraturan-peraturan negara ialah: ${ }^{25}$

1. Undang-Undang;

2. Peraturan Pemerintah;

3. Perpu/Peraturan Pemerintah Pengganti Undang-Undang;

4. Penetapan Presiden;

5. Peraturan Presiden;

6. Peraturan Pemerintan untuk melaksanakan Peraturan Presiden;

7. Keputusan Presiden, dan

8. Peraturan/Keputusan Menteri. ${ }^{26}$

Setelah tumbangnya Pemerintahan Orde Lama, dan memasuki pemerintahan Orde Baru, surat Presiden Soekarno dikembangkan oleh DPR Gotong Royong dan hasilnya di awal Orde Baru ditetapkanlah TAP MPRS No. XX/MPRS/1966 tentang Memorandum DPR-GR mengenai Sumber Tertib Hukum Republik Indonesia dan Tata Urutan Peraturan Perundangan Republik Indonesia. Dalam Lampiran II TAP

${ }^{25}$ Ibid., hal 108 .

26 Dalam susunan tersebut tidak dimasukkan UUD dan TAP MPR. Hal ini disebabkan karena MPR belum terbentuk, sedangkan UUD tidak dimasukkan karena bukan peraturan Negara melainkan hukum dasar Negara yang berada di atas peraturan Negara tersebut. (Lihat: Natabaya, Ibid., hal. 109). 
MPRS tersebut, menyebutkan Bentuk dan Tata Urutan Peraturan Perundangan Republik Indonesia, yaitu: ${ }^{27}$

1. Undang-Undang Dasar 1945;

2. Ketetapan MPR;

3. Undang-Undang/Perpu (Peraturan Pemerintah Pengganti UndangUndang);

4. Peraturan Pemerintah;

5. Keputusan Presiden;

6. Peraturan-peraturan pelaksanaan lainnya seperti :

a. Peraturan Menteri;

b. Instruksi Menteri; dan lain-lain.

Setelah runtuhnya pemerintahan Orde Baru yang dimulai dengan Sidang Istimewa MPR tahun 1999, kemudian dilanjutkan dengan sidang tahunan MPR tahun 2000, barulah MPR menetapkan TAP MPR No. III/MPR/2000 tentang Sumber Hukum dan Tata Urutan Peraturan Perundang-undangan sebagai pengganti TAP MPRS No. XX/MPRS/1966.

Jenis/bentuk dan tata urutan/susunan (hirarki) Peraturan Perundang-undangan yang diatur dalam Pasal 2 TAP MPR No. III/MPR/2000 adalah: ${ }^{28}$

1. UUD Negara RI Tahun 1945;

2. Ketetapan (TAP) MPR;

3. Undang-Undang (UU);

4. Peraturan Pemerintah Pengganti Undang-Undang (Perpu);

5. Peraturan Pemerintah (PP);

6. Keputusan Presiden (Keppres);

7. Peraturan Daerah (Perda). ${ }^{29}$

${ }^{27}$ H.A.S.Natabaya. Op. Cit., hal. 112.

${ }^{28}$ Ibid., hal. 20.

29 Dari susunan tersebut. masih terdapat kekurangan karena ada jenis peraturan perundangan yang belum terakomodasi di dalamnya yang sifatnya mengatur (regeling). antara lain:

- Peraturan Mahkamah Agung;

- Keputusan Kepala/Ketua BPK:

- Peraturan Bank Indonesia;

- Keputusan Menteri:

- Keputusan Kepala LPND/Komisi/Badan.

(Lihat: Natabaya, Ibid., hal 124.) 
Pada Sidang Tahunan MPR tahun 2003. MPR menetapkan TAP MPR No. I/MPR/2003 tentang Peninjauan Kembali Terhadap Materi dan Status Hukum TAP MPRS dan TAP MPR RI sejak tahun 1960 Sampai Dengan Tahun 2002.

Berdasarkan TAP MPR No. I/MPR/2003 kemudian dilahirkan Undang-Undang No. 10 Tahun 2004 tentang Pembentukan Peraturan Perundang-Undangan, sebagai pengganti TAP MPR No. I/MPR/2000. Jenis dan tata urutan/susunan (hirarki) peraturan perundang-undangan yang diatur dalam Pasal 7 Undang-Undang tersebut adalah: ${ }^{30}$

1. Undang-Undang Dasar Negara Republik Indonesia Tahun 1945;

2. Undang-Undang/Peraturan Pemerintah Pengganti UndangUndang;

3. Peraturan Pemerintah;

4. Peraturan Presiden;

5. Peraturan Daerah.

Sesuai dengan ketentuan dalam Pasal 7 ayat (3) dan (4) UU No. 10/2004 beserta penjelasannya (yang bersifat fleksibel) maka masih dimungkinkan adanya jenis peraturan perundang-undangan lainnya dengan syarat sepanjang ditentukan oleh suatu peraturan perundangundangan baik melalui kewenangan atribusi atau delegasi dari peraturan perundang-undangan yang bersangkutan atau diperintahkan oleh suatu peraturan perundang-undangan yang lebih tinggi.

\section{Materi Muatan Peraturan Perundang-undangan}

Materi muatan Peraturan perundang-undangan adalah materi yang dimuat dalam Peraturan Perundang-undangan sesuai dengan jenis. fungsi, dan hirarki Peraturan Perundang-undangan. ${ }^{31}$

Di dalam Pasal 6 Undang-Undang No. 10 tahun 2004, ditetapkan beberapa asas yang harus terkandung di dalam materi peraturan perundangundangan, antara lain: ${ }^{32}$

a. Asas pengayoman adalah bahwa setiap materi muatan peraturan perundang-undangan harus berfungsi memberikan

${ }^{30}$ Ibid., hal. 140.

${ }^{31}$ Indonesia (C). Undang-Undang No. 10 Tahun 2004 tentang Pemhentukan Peraturan Perundang-undangan, Pasal 1 butir (12).

${ }^{32}$ H.A.S. Natabaya, Ibid., hal. 35 . 
perlindungan dalam rangka menciptakan ketentraman masyarakat;

b. Asas kemanusiaan adalah bahwa setiap materi muatan peraturan perundang-undangan harus mencerminkan perlindungan dan penghormatan hak-hak asasi manusia serta harkat dan martabat setiap warga Negara dan penduduk Indonesia secara proporsional;

c. Asas kebangsaan adalah bahwa setiap materi muatan peraturan perundang-undangan harus mencerminkan sifat dan watak bangsa Indonesia yang pluralistik dengan tetap menjaga prinsip Negara Kesatuan Republik Indonesia;

d. Asas kekeluargaan adalah bahwa setiap materi muatan peraturan perundang-undangan harus mencerminkan inusyawarah untuk mencapai mufakat dalam setiap pengambilan keputusan;

e. Asas kenusantaraan adalah bahwa setiap materi muatan peraturan perundang-undangan senantiasa memperhatikan kepentingan seluruh wilayah Indonesia dan materi muatan peraturan perundang-undangan yang dibuat di daerah merupakan bagian dari sistem hukum nasional yang berdasarkan Pancasila dan UUD Negara RI Tahun 1945;

f. Asas bhinneka tunggal ika adalah bahwa setiap materi muatan peraturan perundang-undangan harus memperhatikan keragaman penduduk, agama, suku dan golongan, kondisi khusus daerah, dan budaya khususnya yang menyangkut masalah-masalah sensitif dalam kehidupan bermasyarakat, berbangsa dan bernegara;

g. Asas keadilan adalah bahwa setiap materi muatan peraturan perundang-undangan harus mencerminkan keadilan secara proporsional bagi setiap warga negara tanpa kecuali;

h. Asas kesamaan kedudukan dalam hukum dan pemerintahan adalah bahwa setiap materi muatan peraturan perundang-undangan tidak boleh berisi hal-hal yang bersifat membedakan berdasarkan latar belakang, antara lain agama, suku, ras, golongan, gender, maupun status sosial;

i. Asas ketertiban dan kepastian hukum adalah bahwa setiap materi muatan peraturan perundang-undangan harus dapat menimbulkan ketertiban dalam masyarakat melalui jaminan adanya kepastian hukum;

j. Asas keseimbangan, keserasian, dan keselarasan adalah bahwa setiap materi muatan peraturan perundang-undangan 
harus mencerminkan keseimbangan, keserasian, dan keselarasan, antara kepentingan individu dan masyarakat dengan kepentingan bangsa dan negara.

Kesepuluh asas-asas tersebut haruslah terefleksi di dalam setiap materi peraturan perundang-undangan yang dibuat di Negara RI. Asasasas tersebut juga tidak terlepas harus terefleksi di dalam peraturan di bidang perbankan Indonesia, yaitu peraturan Bank Indonesia.

\section{Peraturan Bank Indonesia}

Bank Indonesia merupakan organ/lembaga yang mandiri dan merupakan bank sentral sebagaimana ditentukan dalam Pasal 23D UUD Negara RI Tahun 1945 dapat membuat peraturan yang bernama Peraturan Bank Indonesia (dasar hukumnya, Pasal 1 angka 8 UU No. 23 Tahun 1999 tentang Bank Indonesia). Dasar hukum pembentukan Peraturan Bank Indonesia dalam konteks ini juga adalah Pasal 7 ayat (4) UU No. 10 Tahun 2004 tentang Pembentukan Peraturan Perundang-undangan.

\section{A. Materi Muatan Peraturan Bank Indonesia}

Materi muatan Peraturan Bank Indonesia adalah hal-hal yang perlu diatur lebih lanjut dengan Peraturan Bank Indonesia yang merupakan peraturan pelaksanaan dari Undang-Undang No. 23 Tahun 1999 tentang Bank Indonesia yang berkaitan dengan tujuan dan tugas Bank Indonesia mengenai kestabilan rupiah, kebijakan moneter, kelancaran sistem pembayaran, dan pengawasan perbankan.

Materi muatan Peraturan Bank Indonesia berisi materi yang diperintahkan oleh Undang-Undang Bank Indonesia. Undang-Undang Bank Indonesia mengeluarkan dua jenis atau bentuk peraturan perundang-undangan yang baru, yaitu Peraturan Bank Indonesia dan Peraturan Dewan Gubernur.

\section{B. Peraturan Bank Indonesia dan Peraturan Dewan Gubernur Bank Indonesia}

Peraturan Bank Indonesia adalah ketentuan hukum yang ditetapkan oleh Bank Indonesia dan mengikat setiap orang atau badan dan dimuat dalam Lembaran Negara Republik Indonesia. ${ }^{33}$

${ }^{33}$ Indonesia (A), Loc. Cit., Pasal 1 ayat (8). 
Fungsi Peraturan Bank Indonesia adalah untuk menyelenggarakan lebih lanjut ketentuan Undang-Undang No. 23 Tahun 1999 tentang Bank Indonesia yang berkaitan dengan tujuan dan tugas Bank Indonesia mengenai kestabilan rupiah, kebijakan moneter, kelancaran sistem pembayaran, dan pengawasan perbankan.

Beberapa peraturan yang dikeluarkan oleh Bank Indonesia yang berkaitan dengan tujuan dan tugas Bank Indonesia mengenai kestabilan rupiah, kebijakan moneter, kelancaran sistem pembayaran, dan pengawasan perbankan, dapat diuraikan sebagai berikut: ${ }^{34}$

- SK DIR BI No. 32/33/KEP/DIR tanggal 12 Mei 1999 tentang Bank Umum;

- SK DIR BI No. 32/34/KEP/DIR tanggal 12 Mei 1999 tentang Bank Umum Berdasarkan Prinsip Syariah;

- SK DIR BI No. 32/35/KEP/DIR tanggal 12 Mei 1999 tentang Bank Perkreditan Rakyat;

- SK DIR BI No. 32/36/KEP/DIR tanggal 12 Mei 1999 tentang Bank Perkreditan Rakyat Berdasarkan Prinsip Syariah;

- SK DIR BI No. 32/37/KEP/DIR tanggal 12 Mei 1999 tentang Persyaratan dan Tata Cara Pembukaan Kantor Cabang, Kantor Cabang Pembantu dan Kantor Perwakilan Dari Bank Yang Berkedudukan di Luar Negeri;

- SK DIR BI No. 32/50/KEP/DIR tanggal 14 Mei 1999 tentang Persyaratan dan Tata Cara Pembelian Saham Bank Umum;

- SK DIR BI No. 32/51/KEP/DIR tanggal 14 Mei 1999 tentang Persyaratan dan Tata Cara Merger, Konsolidasi dan Akuisisi Bank Umum;

- SK DIR BI No. 32/52/KEP/DIR tanggal 14 Mei 1999 tentang Persyaratan dan Tata Cara Merger, Konsolidasi dan Akuisisi Bank Perkreditan Rakyat;

- SK DIR BI No. 32/53/KEP/DIR tanggal 14 Mei 1999 tentang Tata Cara Pencabutan Izin Usaha, Pembubaran dan Likuidasi Bank Umum;

- SK DIR BI No. 32/54/KEP/DIR tanggal 14 Mei 1999 tentang Tata Cara Pencabutan Izin Usaha, Pembubaran dan Likuidasi Bank Perkreditan Rakyat;

${ }^{34}$ Sjahdeini, Loc .Cit., hal. 14. 
- Peraturan Bank Indonesia No. 1/6/PBI/1999 tanggal 20 September 1999 tentang Penugasan Kepatuhan dan Penerapan Standar Pelaksanaan Fungsi Audit Intern Bank Umum.

Sedangkan Peraturan Dewan Gubernur adalah ketentuan hukum yang ditetapkan oleh Dewan Gubernur yang memuat aturan-aturan antara lain mengenai tata tertib pelaksanaan tugas dan wewenang Dewan Gubernur, kepegawaian dan organisasi Bank Indonesia. ${ }^{35}$

\section{Kedudukan Peraturan Bank Indonesia Dipandang dari Sudut Undang-Undang RI No. 10 Tahun 2004 tentang Pembentukan Peraturan Perundang-undangan}

Undang-Undang No. 10 Tahun 2004 mengatur tentang jenis dan tata urutan/susunan (hirarki) peraturan perundang-undangan di dalam Pasal 7, yang antara lain terdiri dari: ${ }^{36}$

1. Undang-Undang Dasar Negara Republik Indonesia Tahun 1945;

2. Undang-Undang/Peraturan Pemerintah Pengganti UndangUndang;

3. Peraturan Pemerintah;

4. Peraturan Presiden;

5. Peraturan-Daerah.

Sesuai dengan ketentuan dalam Pasal 7 ayat (3) dan (4) beserta penjelasannya (yang bersifat fleksibel), maka masih dimungkinkan adanya jenis peraturan perundang-undangan lainnya dengan syarat sepanjang ditentukan oleh suatu peraturan perundang-undangan baik melalui kewenangan atribusi atau delegasi dari peraturan perundangundangan yang bersangkutan atau diperintahkan oleh suatu peraturan perundang-undangan yang lebih tinggi.

Jika mempelajari jenis dan tata urutan/susunan tersebut, maka Peraturan Bank Indonesia mempunyai kedudukan yang sejajar dengan Peraturan Presiden, mengingat Peraturan Bank Indonesia berfungsi untuk menyelenggarakan lebih lanjut ketentuan Undang-Undang No. 23 Tahun 1999 tentang Bank Indonesia yang berkaitan dengan tujuan dan tugas Bank

\footnotetext{
${ }^{35}$ Sjahdeini, Ibid.. hal. 97.

${ }^{36}$ Jbid., hal. 140.
} 
Indonesia mengenai kestabilan rupiah, kebijakan moneter, kelancaran sistem pembayaran, dan pengawasan perbankan.

\section{Penutup}

Kegiatan utama dari suatu bank adalah menghimpun dana dari masyarakat dan menyalurkannya kembali dalam bentuk kredit kepada masyarakat. Sampai saat ini kegiatan pemberian kredit bank-bank di Indonesia masih merupakan sumber pendapatan utama bagi bank. Bentuk pendapatan bank yang diperoleh dari pemberian kredit itu adalah berupa bunga kredit, atau yang disebut interest income.

Bank Indonesia merupakan satu-satunya bank di Indonesia yang mengemban fungsi sebagai bank sentral. Pelaksanaan fungsi dari suatu bank sentral memegang peranan yang sangat penting dan sangat menentukan dalam kehidupan perekonomian suatu negara. Demikian berpengaruhnya bagi kehidupan perekonomian negara, sehingga Bank Indonesia sebagai bank sentral harus berkiprah sejalan dengan perubahan tatanan perekonomian yang sedang berlangsung, yaitu dari command economy kepada market economy.

Sebagai pembina dan pengawas perbankan di Indonesia, Bank Indonesia dalam menjalankan peran dan fungsinya tidak terlepas dari tujuannya yang diatur secara eksplisit di dalam undang-undang. Tujuan Bank Indonesia adalah mencapai dan memelihara kestabilan nilai rupiah. Untuk mencapai tujuan serta menjalankan peran dan fungsinya, Bank Indonesia mengeluarkan Peraturan Bank Indonesia. Peraturan Bank Indonesia adalah ketentuan hukum yang ditetapkan oleh Bank Indonesia dan mengikat setiap orang atau badan dan dimuat dalam Lembaran Negara Republik Indonesia.

Jika mempelajari jenis dan tata urutan/susunan yang diatur di dalam Undang-Undang No. 10 Tahun 2004 tentang Pembuatan Peraturan Perundang-Undangan, maka Peraturan Bank Indonesia mempunyai kedudukan yang sejajar dengan Peraturan Presiden, mengingat Peraturan Bank Indonesia berfungsi untuk menyelenggarakan lebih lanjut ketentuan Undang-Undang No. 23 Tahun 1999 tentang Bank Indonesia yang berkaitan dengan tujuan dan tugas Bank Indonesia mengenai kestabilan rupiah, kebijakan moneter, kelancaran sistem pembayaran, dan pengawasan perbankan. 


\section{Daftar Pustaka}

\section{Buku}

Adi, Rianto. Metodologi Penelitian Sosial dan Hukum, Jakarta: Granit, 2004.

Barnes, A James et.al. Law For Business, Illinois: Richard D. Irwin Inc., 1987.

Creswell, John W. Research Design (Qualitative \& Quantitative Approaches), London: Sage Publication, 1999.

Day, DM and Bernadette Griffin. The Law of International Trade. Second edition, London: Butterworths, 1993.

Dooley, David. Social Research Methods, Third edition, New Jersey : Prentice Hall, 1995.

Dunfee, Thomas W., et.al. A Modern Business Law. New York: Random House Business Division, 1989.

E. Mauch, James and Jack W. Birch. Guide To The Successful Thesis And Dissertation. A handbook for student and faculty. New York: Marcel Dekker Inc., 1993.

F. Fox JR, William. International Commercial Agreements, Den Haag: Kluwer Law International, 1992.

Freeman, MDA. Lloyd's Introduction To Jurisprudence. Seventh edition. London: Sweet \& Maxwell Ltd, 2001.

Friedmann, W. Teori \& Filsafat Hukum (Hukum \& Masalah-Masalah Kontemporer), Cetakan pertama, Jakarta: Rajawali Pers, 1990.

Garner, A.Bryan. ed. Black's Law Dictionary, Seventh edition, St. Paul Minnesota: West Publishing \& Co. 1995.

Gautama, Sudargo. Indonesian Business Law, Cetakan I. Bandung: PT. Citra Aditya Bakti, 1995.

Kamus Hukum Ekonomi ELIPS. Edisi pertama, Jakarta: ELIPS, 1997.

Natabaya, H.A.S. Sistem Peraturan Perundang-Undangan Indonesia, Jakarta: Sekretariat Jenderal dan Kepaniteraan Mahkamah Konstitusi RI, 2006.

Sjahdeini, Sutan Remy. Kapita Selekta hukum Perbankan: Himpunan Tulisan, Teaching Materials Program Magister Fakultas Humum UI, 1999. 
, The Commercial Laws of Indonesia, Cetakan I, Bandung : PT. Citra Aditya Bakti, 1998.

, Himpunan Peraturan-Peraturan Baru Bidang Hukum Ekonomi Yang Penting Untuk Praktek Sehari-hari, Cetakan I, Bandung : PT.Citra Aditya Bakti, 2001.

Hardjasoemantri, Koesnadi and Naoyuki Sakumoto (editor). Current Development of Laws In Indonesia, Tokyo: Insitute of Developing Economics, Japan External Trade Organization, 1999.

Mamudji, Sri dan Hang Rahardjo. Tehnik Menyusun Karya Tulis Ilmiah, Bahan Kuliah Metodologi Penelitian Hukum. Edisi Keempat, Jakarta : 1999.

Mays, Abla J. Lex Situs: The Law of The Place Where The Property is Situated, London: Cavendish Publishing Ltd., 1996.

Morris, JHC. Contemporary Part Laws In the Conflict of Laws, Leyden/Boston: The British Institute of International \& Comparative Law, 1978.

, And PM North, Cases And Materials on Private Internaional Law, London: Butterworths, 1984.

Rajagukguk, Erman. Perbandingan Sistim Hukum Civil Law \& Common Law, Bahan Diskusi Program Doktor, Jakarta : Program Pasacasarjana FHUI 2004.

, Peranan Hukum dalam Pembangunan Ekonomi, Bahan Diskusi Program Doktor, Jakarta: Program Pascasarjana, FHUI, 2004.

, Hukum Investasi di Indonesia, Depok: Badan Penerbit Fakultas Hukum UI, 2006.

Rahardjo, Satjipto. Ilmu Hukum, Jakarta: Balai Pustaka, 1979.

Rasjidi, Lili. Filsafat Hukum (Apakah Hukum Itu?), Cetakan kelima, Bandung: PT Remaja Rosda Karya, 1991.

Sakumoto, Naoyuki and Hikmahanto Juwana (editor). Reforming Laws and Institutions in Indonesia: An Assessment, Depok: Penerbit Fakultas Hukum UI, 2007.

Wigjnosoebroto, Soetandyo. HUKUM Paradigma, Metode dan Dinamika Masalahnya, Jakarta: ELSAM \& HUMA, 2002.

Williams, Glanville. Learning The Law, Tenth edition, London: Steven \& Sons, 1978. 


\section{Artikel}

Pradjoto, "Aspek Hukum Jaminan Dalam Coorporate Financing oleh Perbankan di Indonesia: Aturan Penegakan dan Penyelesaian Sengketa hukum Dalam Hubungan Kreditur dan Debitur", makalah yang disampaikan dalam seminar sehari perbankan: Aspek Hukum Dalam Coorporate Finance Oleh Perbankan Di Indonesia, yang diselenggarakan oleh Jurnal Hukum dan Pembangunan di Fakultas Hukum UI (Depok, 17 Juli 2006): hal. 2.

Sjarif, Ahlan Irsjan, "COORPORATE FINANCE Perkembangan, Prospek dan Kendalanya Ditinjau dari Hukum Indonesia", makalah yang disampaikan dalam seminar sehari perbankan: Aspek Hukum Dalam Coorporate Finance Oleh Perbankan Di Indonesia, yang diselenggarakan oleh Jurnal Hukum dan Pembangunan di Fakultas Hukum UI (Depok, 17 Juli 2006): hal. 2.

\section{Peraturan Perundang-undangan}

Indonesia. Undang-Undang No. 13 Tahun 1968 tentang Bank Sentral. , Undang-Undang No. 7 Tahun 1992 tentang Perbankan , Undang-Undang No. 10 tahun 1998 tentang Perubahan Atas Undang-Undang No. 7 Tahun 1992 tentang Perbankan. , Undang-Undang No. 23 Tahun 1999 tentang Bank Indonesia , Undang-Undang No. 10 Tahun 2004 tentang Pembentukan Peraturan Perundang-Undangan. 